\title{
Las preocupaciones de Enrique José Varona
}

Los historiadores de la literatura en Hispanoamérica van situando ya a cada maestro o guiador en su lugar. Varona adoctrinó y guió la conciencia cubana durante unos cincuenta años. Ha sido una fuerza de las más discernibles en la formación espiritual de la gran Antilla. Desaparecido hace poco, se empieza ahora a examinar su obra, a demandarle su sentido, en lo cultural, en lo nacional.

En mi reciente libro Varona, maestro de juventudes he estudiado con algún detenimiento la personalidad del escritor y el filósofo cubano a quien se consideró en el pás, desde I88o, año más o menos, como una figura de la jerarquía mental y moral de los Saco, Luz y Caballero, Varela... En este artículo acentúo sus preocupaciones cubanas, que fueron tres, vistas esencialmente: la superación del espíritu colonial, que ha rebasado la fecha de 1895 ; la política, entendida como arte de buen gobierno, y, en la esfera intelectual, el cultivo de los altos estudios entre nosotros.

La vida de Varona alcanza una gran unidad porque toda ella estuvo llena de esas fundamentales preocupaciones, y la grandeza del siglo XIX en Cuba radica en que hubo hombres preocupados. Sin esto, las sociedades y las épocas pasan carentes de sentido histórico. Preocupación denota tensión individual que de algún modo se convierte en colectiva. Cuando no se da 
este fenómeno, la sociedad es floja espiritualmente: no existen valores.

Enrique José Varona vivió cabalmente con esa preocupación: la de los valores.

Preocupábale la persistencia en Cuba de los modos administrativos y políticos coloniales. Alguna vez lo declaró: "I a colonia se nos viene encima". Con lo cual significaba que la mera independencia no podría bastarnos. Claro que durante el período revolucionario y de contienda bélica, la independencia (que escribíamos con mayúscula) era un fin. Una vez obtenida, su rango se tornó en medio. Ya Martí, que no iba a ser testigo de esos modos coloniales que rebasaron la fecha de 1895 , había dicho, como si los presintiera: "La República no consiste en el cambio de forma, sino en el cambio de espíritu".

La independencia como un "medio" para fomentar una comunidad superior: tal ha sido en ellos la visión.

Por eso Varona, en la política al uso en Cuba, no fué nunca lo que aquí se ha llamado "hombre de partido". Y es que para conciencias como la suya hay un orden jerárquico que es éste: primero, lo humano; segundo, lo nacional; tercero, lo que interesa al partido. Inviértase este orden y se tendrá el que adoptan los mediocres, los desaprensivos, los que, según otra frase en boga, están "en la realidad". No ven que la realidad no es una sola. No sospechan que el mundo de lo histórico y de lo espiritual tiene la suya, sin la cual descendemos al plano del mero comer, procrear...

Los vicios del sufragio, el entronizamiento del caciquismo, el súbito enriquecimiento de algunos hombres públicos, he ahí los males que con más preocupación combatió Varona.

En su credo político se mantuvo dentro del ideario liberal, clemocrático, parlamentarista del siglo XIX. Desde luego el término liberal no denota en este caso la orientación de los llamados partidos liberales en América. Varona, durante la República, figuró en el partido conservador. Su liberalismo era en el sentido universal que atañe a la libertad de pueblos y de individuos. $Y$ : en cuanto a democracia, no confió mucho en el demos, antes bien, quisio reducirle la esfera, al propugnar, en 
conferencia memorable, el sufragio restringido, con razones que si no debían ni podían triunfar, serán siempre muy atendibles.

Fué Varona desde 1875 , año más o menos, un dirigente autorizadísimo en las letras y en el pensamiento cubano. Se le llama a menudo el filósofo. Está bien. Lo fué, de fijo, y su curso empezado en I88o constituye una de las más altas realizaciones filosóficas en Hispanoamérica. En verdad, la más coherente y mejor escrita.

Pero Varona alcanza en literatura un relieve no menor. Su extensa labor de crítico logra fisonomía singular, aun con haberse producido en un país donde la crítica literaria tenía ya envidiable tradición. Contemporáneos suyos fueron Piñeyro y Sanguily, que en algún aspecto lo igualan. En conjunto, Varona tiene más fuerza, por la penetración y por la doctrina. En tal o cual área de las literaturas europeas, no fué tan erudito como $\mathrm{Pi}-$ ñeyro o Justo de Lara, por ejemplo; pero cuando Varona enjuicia a Cervantes y a Martí, su lección va a comentarse y aprovecharse por muchos años. Y en el artículo breve, de que tanto gustó, fué un maestro de crítica difícil de superar. Léanse para confirmarlo sus dos libros Desde mi Belvedere y Violetas y ortigas.

No perdió nunca su contacto con Europa en literatura. Algo lo descuidó en Filosofía, a partir de rgoo. Yo he subrayado en otra parte que Varona se dió preferentemente a lo literario, no a lo filosófico, en sus últimos quince o veinte años. Su dedicación a la Filosofía fué discontinua, al menos en la producción; su dedicación a las letras fuè constante.

La conferencia sobre Cervantes (I883) dejaba abierto el cauce a la renovación de la críica. Esta no es alli de formalismo académico, de valores granaticales, de pautas de Preceptiva, sino escrutadora de épocas y de individualidades, y por eso, explicativa del esencial sentido de la obra de arte. Por tan egregio modo adoctrinó sobre cómo deben enjuiciarse y apreciarse hombres y libros. Deleite ha sido aquella pieza y lección magna.

Volvió sobre el tema con ocasión del tricentenario del Quijote, en 1905. Y fueron páginas luminosas.

Varona ha sido el más grande de los articulistas cubanos ( $y$ 
es sólo un lado de su obra). En el escrito corto, concentrado, de actualidad por lo general, lograba verdaderos aciertos. Algunos de sus artículos tienen rango de ensayos, por lo que esbozan y sugieren. Escribió centenares, siempre acerca de política y de literatura o arte. A más de los libros mencionados, sirve para comprobarlo, el titulado De la Colonia a la República, cuya segunda parte se compone de artículos políticos muy breves, indicadores de su cubanidad preocupada, vi. gilante.

He sostenido en mi libro Varona, maestro de juventudes y en mi reciente curso en la Academia de Ciencias de la Habana sobre "Las doctrinas filosóficas en Cuba", que Varona siguió y enseñó la menos fecunda de las filosofías: el Positivismo, sin que atendiera a otros movimientos de fines del siglo XIX, como la dirección neokantiana, por ejemplo.

Al ceñirse nuestro filósofo al dato, al experimento, y renunciar a toda especulación metafísica, suprime los problemas. (Es lo que hace el Positivismo al no poder resolverlos).

Los tres cursos de Varona son excelente modelo de prosa didáctica. Disciplinan, por el rigor de su método, por su claridad, por su honradez intelectual. Pero apenas dibujan perspectivas al espíritu. No podía ser de otro modo: lo puramente empírico agota pronto su mensaje. La experiencia - de cuyo predio no sale Varona-, no es capaz de satisfacer la apetencia mental. La curiosidad por lo trascendente es tan vieja como el hombre, y Varona la reprime, la desvía. Por eso, con ser un alto maestro, ni avivó entre nosotros el interés filosófico ni dejó discípulos. Yo diría que han quedado discípulos de su persona, no de su doctrina. $Y$ acaso él replicara: -Después de todo, eso es lo mejor.- Porque el hombre, eso sí, era un austero ejemplar de humanidad.

Tomémosle, pues, como filósofo inclusive, tal como fué. Cierto que no superó el Positivismo, como D. Alejandro Korr, cuya cátedra y cuyos libros hallan hoy evidente resonancia en la Argentina y fuera de ella, pero sirvió altamente a la disciplina del pensar, a la renovación de la crítica literaria y a la dignidad ciudadana. 